\title{
Reboost Image Segmentation using Genetic Algorithm
}

\author{
Ashutosh Jaiswal \\ Computer Science Department \\ IMS Engineering College, \\ Ghaziabad, \\ U.P., India
}

\author{
Lavika Kurda \\ Computer Science Department \\ IMS Engineering College, \\ Ghaziabad, \\ U.P., India
}

\author{
Vijai Singh \\ Computer Science Department \\ IMS Engineering College, \\ Ghaziabad, \\ U.P., India
}

\begin{abstract}
This paper present a Improved Algorithm for Image Segmentation System for a RGB colour image, and presents a proposed efficient colour image segmentation algorithm based on evolutionary approach i.e. improved Genetic algorithm. The proposed technique, without any predefined parameters determines the optimum number of clusters for colour images. The optimal number of clusters is obtained by using maximum fitness value of population selection. The advantage of this method lies in the fact that no prior knowledge related to number of clusters is required to segment the color image. Proposed algorithm strongly supports the better quality of segmentation. Experiments on standard images have given the satisfactory and comparable results with other techniques.
\end{abstract}

\section{General Terms}

Digital Image Processing, Algorithm, Image Segmentation, Genetic Algorithm.

\section{Keywords}

Color image segmentation, Genetic algorithm, Clustering.

\section{INTRODUCTION}

\subsection{Image Segmentation}

The goal of image segmentation is to cluster pixels into salient image regions, i.e., regions corresponding to individual surfaces, objects, or natural parts of objects. Some works have applied genetic algorithms (GA) to image processing [34] and to segmentation particularly [33, 32, 30, 31]. Indeed, GA is particularly efficient when the search space is really important and when the criterion to optimize is numerically complicated which is always the case in image processing. The main advantages of using GA for segmentation lie in their ability to determine the optimal number of regions of a segmentation result or to choose some features such as the size of the analysis window or some heuristic thresholds. In this paper we deal with various approaches for color image segmentation using GA along with many image segmentation techniques. We have tried to describe general segmentation techniques in this paper. In next section, we illustrate Mestimators algorithm (genetic algorithm), followed by comparison of various approaches led by researchers. Finally we end our work by giving the conclusion and perspectives.

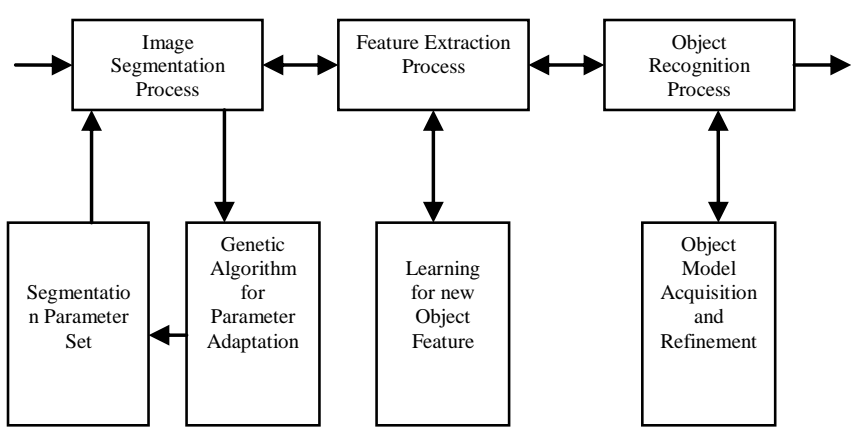

Fig.1: Flow Chart of Image Processing System

\subsection{Genetic Algorithm}

Genetic algorithms are based on natural selection discovered by Charles Darwin [40]. They employ natural selection of fittest individuals as optimization problem solver. Optimization is performed through natural exchange of genetic material between parents. Offspring's are formed from parent genes. Fitness of offspring's is evaluated. The fittest individuals are allowed to breed only. In computer world, genetic material is replaced by strings of bits and natural selection replaced by fitness function. Matting of parents is represented by cross-over and mutation operations.

A simple GA (Figure 1) consists of five steps [29]

1. Start with a randomly generated population of $\mathrm{N}$ chromosomes, where $\mathrm{N}$ is the size of population, $\mathrm{l}$ - length of chromosome $\mathrm{x}$.

2. Calculate the fitness value of function $\varphi(x)$ of each chromosome $\mathrm{x}$ in the population.

3. Repeat until $\mathrm{N}$ offspring's are created:

a. Probabilistically select a pair of chromosomes from current population using value of fitness function.

b. Produce an offspring $y_{i}$ using crossover and mutation operators, where $\mathrm{i}=1,2, \ldots, \mathrm{N}$.

4. Replace current population with newly created one.

5. Go to step 2 . 


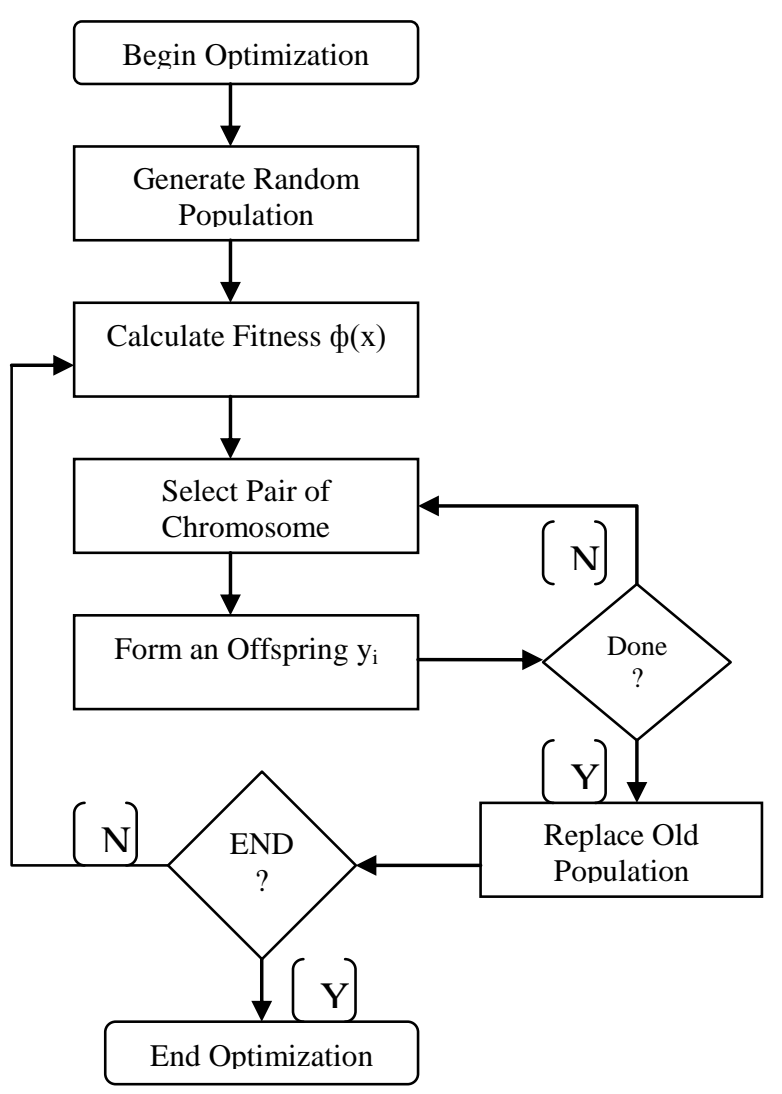

Fig.2: Flow Chart of Genetic Algorithm

\section{LITERATURE REVIEW}

Segmentation of a colour image composed of different kinds of texture regions can be a hard problem, namely to compute for an exact texture fields and a decision of the optimum number of segmentation areas in an image when it contains similar and/or unstationary texture fields. In this work, many researchers have proposed their algorithms for the same.

Vitorino Ramos, Fernando Muge [22] proposed an improvement of the k-means clustering algorithm. This algorithm uses minimum distance criteria as the fitness function. The minimisation is based on the different belonging combinations, of all points in the feature space. Naturally that, such task will be simply if the number of colours in one image to segment is low; however for high number of points in this 3D colour space (i.e., the different number of colours) this minimisation is hard to compute. The respective computer time for segmentation were 14.96, 12.76 and 37.02 minutes when string lengths were 124, 64 and 468 bits long.

ISODATA algorithm [28] proposed by Mohamad Awad, Kacem Chehdi, and Ahmad Nasri has some further refinements by splitting and merging of clusters. Clusters are merged if either the number of members (pixel) in a cluster is less than a certain threshold or if the centres of two clusters are closer than a certain threshold. Clusters are split into two different clusters if the cluster standard deviation exceeds a predefined value, and the number of members (pixels) is twice the threshold for the minimum number of members. 2) ISODATA is the only unsupervised classification method that is used with ERDAS IMAGINE.
P. Scheunders [37] proposed a genetic c-means algorithm which is an improvement to c-means clustering algorithm combining it with genetic algorithm. It is shown that this algorithm is less sensitive to the initial conditions than CMA. Furthermore GCMA is compared to several classical color image quantization algorithms, and its performance is shown to outperform the others, an effect which affects the visual image quality.

The GA-based GAHSI segmentation scheme [23] is a novel and simple approach to robustly segment an outdoor field image into plant and background regions under variable lighting conditions. The GAHSI obtained an equivalent segmentation performance to that obtained by applying cluster analysis to images acquired under specific lighting conditions. To further improve segmentation robustness, different imaging devices and color transformations as well as GA coding and operators need to be investigated in future research.

Li Zhuo et al [38] presented a mew GA based wrapper feature selection method GA-SVM for hyper-spectral data. The results showed that the GA-SVM method could significantly reduce the computation cost while improving the classification accuracy. The number of bands used for classification was reduced from 198 to 13 , while the classification accuracy increased from $88.81 \%$ to $92.51 \%$. The optimized values of the two SVM kernel parameters were 95.0297 and 0.2021 , respectively, which were different from the default values as used in the ENVI software.

\section{GENETIC ALGORITHM BASED CLUSTERING}

The searching capability of GA's can be used for the purpose of appropriately clustering a set of unlabeled points in $\mathrm{N}$ dimension into $\mathrm{K}$ clusters [1]. In our proposed scheme, the same idea can be applied on image data. We consider a colour image of size mxn and every pixel has Red, Green and Blue components. The basic steps of the GA-clustering algorithm for clustering image data are as follows:

\subsection{Encoding}

Each chromosome represents a solution which is a sequence of $\mathrm{K}$ cluster centres. For an $\mathrm{N}$ dimensional space, each cluster centre is mapped to $\mathrm{N}$ consecutive genes in the chromosome. For image datasets each gene is an integer representing an intensity value of the three components Red, Green and Blue.

\subsection{Population initialization}

Population is initialized in various rounds randomly and in each round the best chromosome survives for the next round processing.

\subsection{Fitness computation}

The fitness computation is accomplished in two steps. First, the pixel dataset is clustered according to the centres encoded in the chromosome under consideration, such that each intensity value $\mathrm{x}_{\mathrm{i}}(\mathrm{r}, \mathrm{g}, \mathrm{b})$ of colour image combined with three component red, green and blue ( $24 \mathrm{bit}), \mathrm{i}=1,2, \ldots, \mathrm{mxn}$ is assigned to cluster with centre $\mathrm{z}_{\mathrm{j}}(\mathrm{r}, \mathrm{g}, \mathrm{b}), \mathrm{j}=1,2, \ldots, \mathrm{K}$,

$$
\begin{aligned}
& \text { If } \\
& \|x i(r, g, b)-z j(r, g, b)\|<\|x i(r, g, b)-z p(r, g, b)\| \\
& p=1,2, \ldots k \text { and } p \neq j
\end{aligned}
$$


The next step involves adjusting the values of the cluster centres encoded in the chromosome, replacing them by the mean points of the respective clusters. The new centre $\mathrm{Z}_{\mathrm{i}}(\mathrm{r}, \mathrm{g}, \mathrm{b})$ for the cluster $\mathrm{C}_{\mathrm{i}}$ is given by

$$
Z i(r, g, b)=\frac{1}{n i} \sum_{X j \in C i} X j(r, g, b), i=1,2, \ldots k
$$

Now the fitness metric is computed by calculating the sum of intra cluster spread, i.e. finding the sum of Euclidean distance between the pixels and their respective cluster, given by

$$
\begin{gathered}
M=\sum_{i=1}^{k} M i \\
M \downarrow i=\sum \downarrow(X \downarrow(j \in C \downarrow i)): n\|X \downarrow j(r, g, b)-z \downarrow i(r, g, b)\|
\end{gathered}
$$

The fitness evaluation of a chromosome is given by -

$\mathbf{f}=\mathbf{1} / \mathbf{M}$.....(1), thus our aim is to minimise the value of $\mathrm{f}$.

\subsection{Selection}

Initially the fittest chromosome in every round of random population generation is moved to next generation, in the subsequent processing the fittest chromosome directly holds the $40 \%$ of the entire population and the rest of the population is hold by the chromosomes in the decreasing order of there fitness value.

\subsection{Termination Criterion}

We perform the population generation, fitness computation, crossover and selection for a predetermined number of generations, thus the algorithm is computed for the fixed number of generations and the best solution seen in the entire

\begin{tabular}{|c|c|c|c|c|c|c|c|c|c|}
\hline & 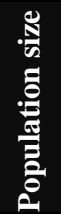 & $\begin{array}{l}\frac{\overline{0}}{3} \\
\frac{8}{8} \\
\frac{8}{8}\end{array}$ & $\begin{array}{l}\dot{0} \\
8 \\
0 \\
0 \\
0 \\
0 \\
0\end{array}$ & 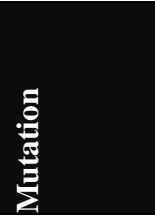 & 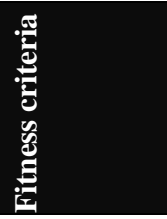 & 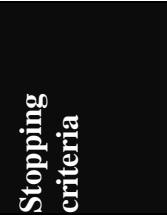 & లె & 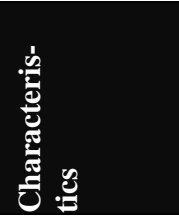 & 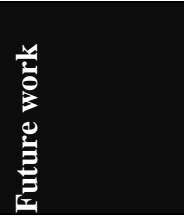 \\
\hline $\begin{array}{l}\text { [22] Parallel } \\
\text { Genetic } \\
\text { Algorithm }\end{array}$ & 100 & $\begin{array}{l}\text { Fitness } \\
\text { proportio } \\
\text { nal } \\
\text { Model }\end{array}$ & $\begin{array}{l}\text { One point } \\
\text { crossover- } \\
\text { Random } \\
\text { selection } \\
\text { of the } \\
\text { point } \\
\text { Crossover } \\
\text { probabilit } \\
\mathrm{y}=0.5\end{array}$ & $\begin{array}{l}\text { Substitutio } \\
\mathrm{n} \text { of a } \\
\text { randomly } \\
\text { generate } \\
\text { integer } \\
\text { Mutation } \\
\text { probability } \\
=0.1\end{array}$ & $\begin{array}{l}\text { Distributio } \\
\mathrm{n} \text { function }\end{array}$ & $\begin{array}{l}\text { Threshold } \\
\text { technique } \\
\text { based on } \\
\text { entropy of } \\
\text { distributed } \\
\text { function }\end{array}$ & $\begin{array}{l}\text { Integer } \\
\text { (Chromoso } \\
\text { me length } \\
=5 \text { ) }\end{array}$ & $\begin{array}{l}\text { Using a } \\
\text { region based } \\
\text { energy } \\
\text { function, the } \\
\text { active } \\
\text { surface } \\
\text { converges } \\
\text { quickly }\end{array}$ & $\begin{array}{l}\text { Automatic } \\
\text { Initialization }\end{array}$ \\
\hline $\begin{array}{l}\text { [23] GAHSI } \\
\text { Algorithm }\end{array}$ & 48 & $\begin{array}{l}\text { Local } \\
\text { tourname } \\
\text { nt } \\
\text { selection } \\
\text { over } \\
\text { roulette } \\
\text { wheel } \\
\text { method }\end{array}$ & $\begin{array}{l}\text { Single } \\
\text { point } \\
\text { crossover } \\
\text { Crossover } \\
\text { probabilit } \\
\mathrm{y}=0.8\end{array}$ & $\begin{array}{l}\text { Insertion } \\
\text { Mutation } \\
\text { probability } \\
=0.03\end{array}$ & $\begin{array}{l}\text { Weighted } \\
\text { average } \\
\text { function }\end{array}$ & $\begin{array}{l}\text { Threshold } \\
\text { technique } \\
\text { based on } \\
\text { UTOPIA } \\
\text { parameter, } \\
\text { if it failed } \\
\text { for } \\
\text { consecutive } \\
5 \text { times }\end{array}$ & Binary & $\begin{array}{l}\text { Use of } \\
\text { different } \\
\text { imaging } \\
\text { devices and } \\
\text { color } \\
\text { transformati } \\
\text { ons }\end{array}$ & $\begin{array}{l}\text { Adaptive } \\
\text { adjustment of } \\
\text { mutation rate }\end{array}$ \\
\hline $\begin{array}{l}{[24]} \\
\text { Optimizatio } \\
\text { n Algorithm }\end{array}$ & 6 & $\begin{array}{l}\text { Normaliz } \\
\text { ed } \\
\text { geometri } \\
\text { c ranking } \\
\text { selection } \\
\text { method, } \\
\text { Selection } \\
\text { probabili } \\
\text { ty }=0.08\end{array}$ & $\begin{array}{l}\text { Arithmeti } \\
\mathrm{c} \\
\text { crossover, } \\
\text { Crossover } \\
\text { probabilit } \\
\mathrm{y}=0.6\end{array}$ & $\begin{array}{l}\text { Non } \\
\text { uniform } \\
\text { mutation, } \\
\text { Mutation } \\
\text { probability } \\
=0.05\end{array}$ & $\begin{array}{l}\text { Supervised } \\
\text { evaluation } \\
\text { function } \\
\text { involving } \\
\text { classificatio } \\
\text { n rate }\end{array}$ & $\begin{array}{l}\text { Stability of } \\
\text { standard } \\
\text { deviation } \\
\text { of the } \\
\text { evaluation } \\
\text { criterion }\end{array}$ & $\begin{array}{l}\text { Based on } \\
\text { genotype }\end{array}$ & $\begin{array}{l}\text { Special } \\
\text { focus on } \\
\text { evaluation } \\
\text { metrics }\end{array}$ & $\begin{array}{l}\text { Implementati } \\
\text { on of priori } \\
\text { knowledge }\end{array}$ \\
\hline
\end{tabular}
generation proceeds to final result.

Table 1. Analysis of Various Algorithms 


\begin{tabular}{|c|c|c|c|c|c|c|c|c|c|}
\hline $\begin{array}{l}{[25,26]} \\
\text { Hybrid } \\
\text { Genetic } \\
\text { Algorithm }\end{array}$ & 31 & $\begin{array}{l}\text { Expected } \\
\text { value } \\
\text { plan and } \\
\text { Elitist } \\
\text { plan are } \\
\text { two } \\
\text { selection } \\
\text { strategies }\end{array}$ & $\begin{array}{l}\text { Unordere } \\
\mathrm{d} \\
\text { Subseque } \\
\text { nce } \\
\text { Exchange } \\
\text { Crossover } \\
\text { (USXX) } \\
\text { and } \\
\text { Ordered } \\
\text { Crossover } \\
\text { Crossover } \\
\text { Probabilit } \\
\text { y=0.6 }\end{array}$ & $\begin{array}{l}\text { Remove } \\
\text { and } \\
\text { Reinsert, } \\
\text { Mutation } \\
\text { Probabilit } \\
\mathrm{y}=0.03\end{array}$ & $\begin{array}{l}\text { Linear } \\
\text { Scaling } \\
\text { function }\end{array}$ & $\begin{array}{l}\text { Threshold } \\
\text { Technique } \\
\text { based on } \\
\text { hybrid } \\
\text { function }\end{array}$ & $\begin{array}{l}\text { GA+SA+H } \\
\text { GAPSA } \\
\text { (Genetic } \\
\text { Algorithm, } \\
\text { Sequential } \\
\text { Algorithm, } \\
\text { Hybrid } \\
\text { Genetic } \\
\text { Algorithm } \\
\text { with } \\
\text { Parallel } \\
\text { Simulated } \\
\text { Annealing }\end{array}$ & $\begin{array}{l}\text { Distributed } \\
\text { environment } \\
\text { with } \\
\text { Remote } \\
\text { Method } \\
\text { Invocation } \\
\text { concept }\end{array}$ & $\begin{array}{l}\text { Removal of } \\
\text { ambiguity in } \\
\text { the } \\
\text { population } \\
\text { size. And } \\
\text { more than } \\
\text { two meta- } \\
\text { heuristic } \\
\text { algorithms } \\
\text { may be } \\
\text { interpreted to } \\
\text { improve the } \\
\text { solution } \\
\text { space. }\end{array}$ \\
\hline $\begin{array}{l}{[27]} \\
\text { Adaptive } \\
\text { Genetic } \\
\text { Algorithm }\end{array}$ & 100 & $\begin{array}{l}\text { Proportio } \\
\text { nal } \\
\text { selection } \\
\text { method }\end{array}$ & $\begin{array}{l}\text { Crossover } \\
\text { Probabilit } \\
\mathrm{y}, 0.5<\mathrm{p}_{\mathrm{c}} \\
<1.0\end{array}$ & $\begin{array}{l}\text { Mutation } \\
\text { Probabilit } \\
\mathrm{y}, 0.001< \\
\mathrm{p}_{\mathrm{m}}<0.05\end{array}$ & $\begin{array}{l}\text { average } \\
\text { fitness } \\
\text { value } \mathrm{f} \text { - } \\
\text { maximum } \\
\text { fitness } \\
\text { value } \\
(\text { fmax }-\mathrm{f})\end{array}$ & $\begin{array}{l}\text { Sub- } \\
\text { averaging } \\
\text { the fitness } \\
\text { value }\end{array}$ & $\begin{array}{l}\text { Based on } \\
\text { Schema } \\
\text { Theorem } \\
\text { i.e. Binary } \\
\text { Coding }\end{array}$ & $\begin{array}{l}\text { GA } \\
\text { repeatedly } \\
\text { converges to } \\
\text { almost same } \\
\text { fitness } \\
\text { values }\end{array}$ & $\begin{array}{l}\text { To resolve } \\
\text { the problem } \\
\text { of getting } \\
\text { stuck in the } \\
\text { local } \\
\text { optimum } \\
\text { when the } \\
\text { population is } \\
\text { scattered. }\end{array}$ \\
\hline $\begin{array}{l}28] \\
\text { ISODATA } \\
\text { Algorithm }\end{array}$ & 90 & $\begin{array}{l}\text { Roulette } \\
\text { wheel } \\
\text { method }\end{array}$ & $\begin{array}{l}\text { Cluster } \\
\text { centre } \\
\text { replaceme } \\
\text { nt method } \\
\text { Crossover } \\
\text { probabilit } \\
\mathrm{y}=0.6\end{array}$ & $\begin{array}{l}\text { Random } \\
\text { substitutio } \\
\mathrm{n} \\
\text { Mutation } \\
\text { probability } \\
=0.1\end{array}$ & $\begin{array}{l}\text { Objective } \\
\text { Function }\end{array}$ & $\begin{array}{l}\text { Stability of } \\
\text { fitness } \\
\text { values for } \\
20 \\
\text { iterations }\end{array}$ & $\begin{array}{l}\text { Bit level } \\
\text { coding }\end{array}$ & $\begin{array}{l}\text { Usage of } \\
\text { multicompo } \\
\text { nent } \\
\text { features }\end{array}$ & $\begin{array}{l}\text { Parallel } \\
\text { cooperation } \\
\text { with more } \\
\text { segmentation } \\
\text { methods, } \\
\text { such as FCM }\end{array}$ \\
\hline $\begin{array}{l}{[36]} \\
\text { Dynamic } \\
\text { GA } \\
\text { based } \\
\text { clustering } \\
\text { (GADCIS) }\end{array}$ & 30 & $\begin{array}{l}\text { Roulette } \\
\text { Wheel } \\
\text { selection }\end{array}$ & $\begin{array}{l}\text { Single } \\
\text { point } \\
\text { crossover } \\
\text { Crossover } \\
\text { probabilit } \\
\mathrm{y}=0.9\end{array}$ & $\begin{array}{l}\text { Substitutio } \\
\mathrm{n} \\
\text { Mutation } \\
\text { probability } \\
=0.01\end{array}$ & $\begin{array}{l}\text { Cluster } \\
\text { validity } \\
\text { criteria } \\
\text { based on } \\
\text { Gaussian } \\
\text { distribution }\end{array}$ & $\begin{array}{l}\text { Fixed no. } \\
\text { of } \\
\text { iterations }\end{array}$ & Integer & $\begin{array}{l}\text { No prior } \\
\text { knowledge } \\
\text { required }\end{array}$ & $\begin{array}{l}\text { Work on } \\
\text { generation of } \\
\text { optimal no. } \\
\text { of cluster } \\
\text { centres }\end{array}$ \\
\hline $\begin{array}{l}\text { [37] Genetic } \\
\text { c-means } \\
\text { clustering } \\
\text { (GCMA) }\end{array}$ & $\begin{array}{l}\text { No. } \\
\text { Of } \\
\text { Clu } \\
\text { ster } \\
\text { s }\end{array}$ & $\begin{array}{l}\text { Roulette } \\
\text { wheel } \\
\text { selection }\end{array}$ & $\begin{array}{l}\text { One point } \\
\text { crossover } \\
\text { Crossover } \\
\text { probabilit } \\
y-=0.8\end{array}$ & $\begin{array}{l}\text { Insertion } \\
\text { of single } \\
\text { bit } \\
\text { Mutation } \\
\text { probability } \\
=0.05\end{array}$ & $\begin{array}{l}\text { Inverse of } \\
\text { MSE }\end{array}$ & $\begin{array}{l}\text { Stability of } \\
\text { MSE }\end{array}$ & $\begin{array}{l}\text { Binary or } \\
\text { other }\end{array}$ & $\begin{array}{l}\text { Develops a } \\
\text { hybrid } \\
\text { algorithm } \\
\text { combining } \\
\text { CMA and } \\
\text { GA }\end{array}$ & $\begin{array}{l}\text { Data } \\
\text { clustering } \\
\text { methods }\end{array}$ \\
\hline $\begin{array}{l}{[38] \text { GA }} \\
\text { (based on } \\
\text { SVM) }\end{array}$ & 20 & $\begin{array}{l}\text { Stochasti } \\
\mathrm{c} \\
\text { uniform }\end{array}$ & $\begin{array}{l}\text { Single } \\
\text { point } \\
\text { crossover } \\
\text { Crossover } \\
\text { probabilit } \\
\mathrm{y}=0.8 \\
\text { scattered }\end{array}$ & $\begin{array}{l}\text { Scale }=1.0 \\
\text { Shrink=1. } \\
0\end{array}$ & $\begin{array}{l}\text { Rank } \\
\text { (fitness } \\
\text { normalizati } \\
\text { on) }\end{array}$ & $\begin{array}{l}\text { Fixed no. } \\
\text { of } \\
\text { iterations }\end{array}$ & Binary & $\begin{array}{l}\text { Classifies } \\
\text { the given } \\
\text { input data } \\
\text { based on a } \\
\text { set of } \\
\text { training } \\
\text { examples }\end{array}$ & $\begin{array}{l}\text { Improvement } \\
\text { in } \\
\text { classification } \\
\text { accuracy }\end{array}$ \\
\hline $\begin{array}{l}\text { [39] Elastic } \\
\text { contour } \\
\text { method }\end{array}$ & 200 & $\begin{array}{l}3 \text { level } \\
\text { contour } \\
\text { function }\end{array}$ & $\begin{array}{l}\begin{array}{l}\text { One point } \\
\text { crossover }\end{array} \\
\text { Crossover } \\
\text { probabilit } \\
y=0.6\end{array}$ & $\begin{array}{l}\text { Substitutio } \\
\mathrm{n} \\
\text { Mutation } \\
\text { probability } \\
=0.0001\end{array}$ & $\begin{array}{l}\text { Normalized } \\
\text { histogram } \\
\text { function }\end{array}$ & $\begin{array}{l}\text { Fitness } \\
\text { value } \\
\text { ranging } \\
\text { around } \\
500-570\end{array}$ & Integer & $\begin{array}{l}\text { GA } \\
\text { repeatedly } \\
\text { converges to } \\
\text { almost same } \\
\text { fitness } \\
\text { values }\end{array}$ & $\begin{array}{l}\text { Deviation of } \\
\text { no. of } \\
\text { variants }\end{array}$ \\
\hline
\end{tabular}




\section{PROPOSED WORK}

The proposed new segmentation algorithm can produce a better result according to the segments created by optimal number of dynamic clusters. We consider a colour image $f$ of size $\mathrm{m} \times \mathrm{n}$. The proposed algorithm is:

1. Repeat step 2 to 4 till fixed no. of generations.

2. Randomly generate the cluster set using the randperm function.

3. Each pixel of the image is associated with the cluster number using min distance function which uses Euclidean formula as criteria.

4. We calculate fitness value of the chromosome by adding the distances of each pixel.

5. The chromosome with maximum fitness value is considered as the solution.

\section{RESULT}

Testing of proposed algorithm with standard color images, it has given satisfactory results, a tabular comparison between different clustering techniques are presented below. Column 2 of table gives the optimal range of clusters as proposed by [12]. Assumptions for segmenting the images are as follows: 20 rounds are processed for generating the initial population each generating random cluster from range 2 to 8 in RGB space, from each round cluster with maximum fitness value is passed to next generation and at each next iteration fitness value is being compared with fitness value of next cluster set. Each next generation contains the maximum fitness value, cluster set and also the cluster numbers. An iteration to 20 generations has been done to create the final results.

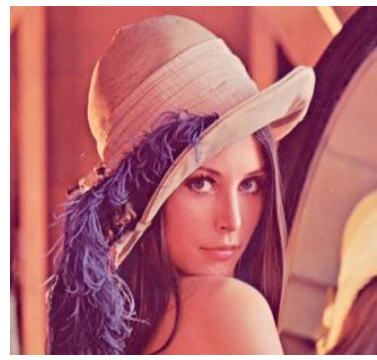

Original Lena image Segmentation method

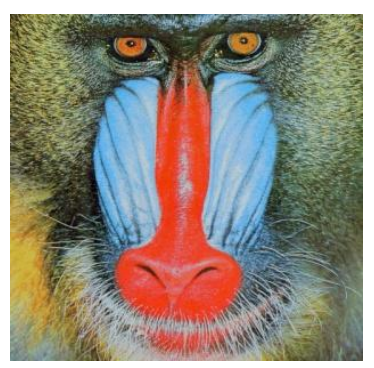

Original Mandril image

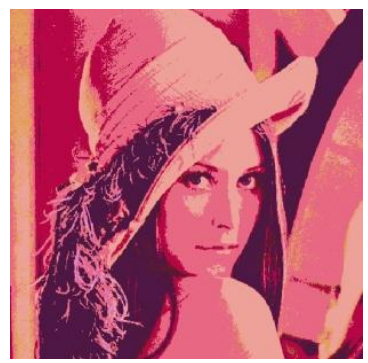

Lena image by proposed

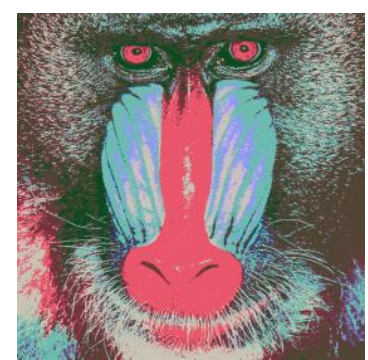

Mandril image by proposed

Segmentation method
Fig.3: Original Image and Segmented Image of Lena \& Mandril
Table 2. Comparison of different Image Segmentation Algorithm

\begin{tabular}{|l|l|l|l|l|}
\hline Image & $\begin{array}{l}\text { Optimal } \\
\text { range }\end{array}$ & $\begin{array}{l}\text { Proposed } \\
\text { method }\end{array}$ & $\begin{array}{l}\text { DCPSO } \\
\text { using v }\end{array}$ & SNOB \\
\hline Mandril & 5 to 10 & 5.32 & 6 & 39 \\
\hline Lena & 5 to 10 & 4.47 & 6.85 & 31 \\
\hline Peppers & 6 to 10 & 6.13 & 6.25 & 42 \\
\hline Jet & 5 to 7 & 4.39 & 5.3 & 22 \\
\hline
\end{tabular}

\section{FUTURE WORK}

The preceding sections provide an overview of the field of image segmentation, the review shows that many current algorithms are able to produce reasonable results on images of moderate complexity; several of these algorithms are efficient enough that they can be used as a pre-processing stage for higher level vision tasks such as recognition and tracking. The GAHSI algorithm [23] has its own characteristics; still it has scope of improvement in adaptive adjustment of mutation rate. Elastic contour method [39] can be improved by automatic deviation of no. of variants. In ISODATA algorithm [28], a parallel cooperation with various segmentation algorithms like FCM is required for further improvement. Still, there is some scope of improvement. Reviewing the existing algorithms, we conclude that absence of prior knowledge about the image's contents, it is in general not possible to determine how many regions are required for a reasonable segmentation. This problem manifests in two forms, Under-segmentation, which occurs when parts of the image that actually correspond to different objects, or to an object and the background, are assigned to the same region; and over-segmentation, which occurs when parts of the image corresponding to a single object are split apart.

\section{CONCLUSION}

Genetic Algorithm has many advantages in obtaining the optimized solution. It was proved to be the most powerful optimization technique in a large space. Genetic algorithm allows performing robust search for finding the global optimum. The result of the optimization depends on the chromosome encoding scheme and involvement of genetic operators as well as on the fitness function. However the quality of image segmentation can be improved by selecting the parameters in an optimized way. The desire for improvement after the GA reached a near optimal stage, led the authors to put some efforts on implementation of prior knowledge applications of GAs in clustering and grouping problems are intensively described in [29]. In the present approach, grey level intensities of RGB image channels are considered as feature vectors, and the k-mean clustering model (J.MacQueen, 1967) is then applied as a quantitative criterion (or GA objective fitness function), for guiding the evolutionary algorithm in his appropriate search.. In present scenario, various fast algorithms for speeding up the process of template matching are being implemented such as Mestimators for dealing with outliers. This fast algorithm ensures finding the global minimum of the robust template 
matching problem in which a non-decreasing M-estimator serves as an error measure.

\section{ACKNOWLEDGMENT}

Our thanks to expert (Vijai Singh), who has guided us to propose a new fast algorithm for image segmentation using genetic algorithm, thus we present our sincere thanks to him and all the others who have contributed towards completion of this paper.

\section{REFERENCES}

[1] W. Frei and C. Chen, "Fast Boundary Detection: A Generalization and New Algorithm," IEEE Trans. Computers, vol. C-26, no. 10, pp. 988-998, Oct. 1977.

[2] J. Canny, "A computational approach to edge detection," IEEE Trans. Pattern Analysis and Machine Intelligence, Vol. 8, No. 6, pp. 679-698, Nov. 1986.

[3] R. C. Gonzalez and R. E. Woods, Digital Image Processing. Upper Saddle River, NJ: Prentice-Hall, 2001, pp. 572-585.

[4] W. K. Pratt, Digital Image Processing. New York, NY: Wiley-Interscience, 1991, pp. 491-556.

[5] Suryakant, Neetu Kushwaha, "Edge Detection using Fuzzy Logic in Matlab,” ISSN: 2277 128X, Volume 2, Issue 4, April 2012.

[6] Gonzalez and Woods, "Digital image processing", 2nd Edition, prentice hall, 2002.

[7] Kenneth R. Castelman, "Digital image processing", Tsinghua Univ Press, 2003.

[8] Du Gen-yuan,Miao Fang,Tian Sheng-li,Guo Xirong.,"Remote Sensing Image Sequence Segmentation Based on the Modified Fuzzy C-means", Journal of Software, Vol. 5, No. 1, PP.28-35, 2009.

[9] N. Senthilkumaran and R. Rajesh, "Edge Detection Techniques for Image Segmentation - A Survey", Proceedings of the International Conference on Managing Next Generation Software Applications (MNGSA-08), 2008, pp.749-760.

[10] Sharmishtha Mitra, Amit Mitra and Debasis Kundu, "Genetic algorithm and M-estimator based robust sequential estimation of parameters of nonlinear sinusoidal signals", Commun Nonlinear Sci Numer Simulat, October 2010.

[11] Jiun-Hung Chen, Chu-Song Chen, and Yong-Sheng Chen, "Fast Algorithm for Robust Template Matching With M-Estimators", IEEE TRANSACTIONS ON SIGNAL PROCESSING, VOL. 51, NO. 1, JANUARY 2003.

[12] Jun Zhang, Kitakyushu Jinglu Hu. "Image Segmentation Based on 2D Otsu Method with Histogram Analysis" Computer Science and Software Engineering, 2008 International Conference

[13] Leo Grady and Eric L. Schwartz "Isoperimetric Graph Partitioning for Image Segmentation"Pattern Analysis and Machine Intelligence, IEEE Transactions.

[14] Pateek Gupta, Sargam Saxena, Sonali Singh, Saumya Dhami and Vijai Singh, "Color Image Segmentation: A State of the Art Survey", International Journal of
Computational Intelligence Research ISSN 0973-1873 Volume 8, Number 1 (2012), pp. 17-25 @ Research India Publications.

[15] Utkarsh Kumar Shah and Prof. A. Mukherjee, "BTP REPORT Image segmentation by region growing", April $15,2010$.

[16] Shilpa Kamdi ${ }^{1}$, R.K.Krishna ${ }^{2}$,1,2-Rajiv Gandhi College of Engineering,Research and Technology, "Image Segmentation and Region Growing Algorithm", feb 1, 2012 ,

[17] S.Beucher, F.Meyer,"The morphological approach to segmentation: The watershed transform", in Mathematical Morphology Image Processing, E. R. Dougherty, Ed. New York Marcel Dekker, 1993, vol. 12, pp. 433-481.

[18] A. N. Moga, M. Gabbouj, "Parallel image component labeling with watershed transformation", IEEE Trans. Pattern Anal. MachineIntell. vol. 19, pp. 441-450. J. M Gauch, "Image segmentation and analysis via multi-scale gradient watershed hierarchies", IEEE Trans Image Processing, vol. 8, pp. 69-79, 2000

[19] O. F. Olsen, M. Nielsen, "Multi-scale gradient magnitude watershed segmentation", in ICIAP' 97-9th Int Conference on Image Analysis and Processing, ser. Lecture Notesin Computer Science. Berlin, Germany: Springer-Verlag, 2001, vol. 1310, pp. 6-13.

[20] JL. Vincent, "Morphological gray scale reconstruction in image analysis: Applications and efficient algorithms", IEEE Trans. Image Processing, vol. 2, 1993.

[21] Mandeep Kaur, Gagandeep Jindal, "Medical Image Segmentation using Marker Controlled Watershed Transformation", IJCST Vol. 2, Issue 4, Oct . - Dec. 2011.

[22] Faguo Yang 3, Tianzi Jiang and Yong Fan , "A Parallel Genetic Algorithm for Cell Image Segmentation" 1;2, 4 National Laboratory of Pattern Recognition, Institute of Automation Chinese Academy of Sciences, Beijing 100080, P. R. China David J. Evans 5 Department of Computing, Nottingham Trent University Nottingham, NG1 4BU, UK.

[23] L. Tang, L. Tian, B. L. Steward , "COLOR IMAGE SEGMENTATION WITH GENETIC ALGORITHM FOR IN-FIELD WEED SENSING".

[24] S. Chabrier, C. Rosenberger, B. Emile Laboratoire TerreOc'ean Universit'e de la Polyn'esie francaise B.P. 6570 98702 FAA'A, Tahiti - Polyn'esie Franaise, Laboratoire GREYC ENSICAEN - Universit'e de Caen - CNRS 6 Boulevard Mar'echal Juin, 14000 Caen cedex, France EURASIP journal on Video and Image processing (2008) $1-23$.

[25] Thamilselvan Rakkiannan and Balasubramanie Palanisamy, "Hybridization of Genetic Algorithm with Parallel Implementation of Simulated Annealing for Job Shop Scheduling" American Journal of Applied Sciences 9 (10): 1694-1705, 2012

[26] Kikuo Fujita, Shinsuke Akagi and Noriyasu Hirokawa, "Hybrid Approach for Optimal Nesting Using a Genetic Algorithm and a Local Minimization Algorithm" Osaka University Suita, Osaka, JAPAN. 
[27] M. Srinivas, and L. M. Patnaik, Fellow, "Adaptive Probabilities of Crossover and Mutation in Genetic Algorithms" IEEE TRANSACTIONS ON SYSTEMS, MAN AND CYBERNETICS, VOL. 24, NO. 4, APRIL 1994.

[28] Mohamad Awad, Kacem Chehdi, and Ahmad Nasri , "Multicomponent Image Segmentation Using a Genetic Algorithm and Artificial Neural Network", IEEE GEOSCIENCE AND REMOTE SENSING LETTERS, VOL. 4, NO. 4, OCTOBER 2007.

[29] Falkenauer, E., "Genetic Algorithms and Grouping Problems", John Wiley \& Sons, Boston, 1998.

[30] Peng-Yeng Yin, "A fast scheme for optimal thresholding using genetic algorithms" Signal Processing, (72):85-95, 1999.

[31] Minglun Gong and Yee-Hong Yang, "Genetic-based multiresolution color image segmentation" Vision Interface, pages 141-148, 2001.

[32] D.N. Chun and H.S. Yang, "Robust image segmentation using genetic algorithm with a fuzzy measure" Pattern Recognition, 7(29):1195-1211, 1996.

[33] B. Bhanu and S. Lee, "Genetic Learning for Adaptive Image Segmentation” Kluwer Academic Press, 1994.

[34] Y. Delignon A. Marzouki and W. Pieczynski, "Estimation of generalized mixtures and its application in image segmentation" IEEE Transactions on Image Processing, 6(10):1364-1375, October 1997.

[35] Zhenyu Wu and Richard Leahy, "An Optimal Graph theoretic approach to data clustering: Theory and its Application to Image Segmentation", IEEE Transactions on pattern analysis and machine intelligence, Vol. 15 No. 11, Nov. 1993.
[36] Amiya Halder and Nilavra Pathak, "An Evolutionary Dynamic Clustering Based Colour Image Segmentation", International Journal of Image Processing (IJIP), Volume (4): Issue (6).

[37] P. Scheunders, “A GENETIC C-MEANS CLUSTERING ALGORITHM APPLIED TO COLOR IMAGE QUANTIZATION", Vision Lab, Dept. of Physics, RUCA University of Antwerp, Groenenborgerlaan 171, 2020 Antwerpen, Belgium.

[38] Li Zhuo, Jing Zheng, Fang Wang, Xia Li, Bin Ai and Junping Qian, "A GENETIC ALGORITHM BASED WRAPPER FEATURE SELECTION METHOD FOR CLASSIFICATION OF HYPERSPECTRAL IMAGES USING SUPPORT VECTOR MACHINE", School of Geographical sciences, Guangzhou University, Guangzhou 510006, China) Commission VII, WG VII/3.

[39] S.Cagnoni, A.B. Dobrezeneicki, R.Pauli, J.C. Yanch, "Genetic algorithm based interactive segmentation of 3D medical images".

\section{AUTHORS' PROFILE}

Ashutosh Jaiswal is a B.Tech Student in Department of Computer Science, IMS Engineering College, Ghaziabad, U.P., India.

Lavika Kurda is a B.Tech Student in Department of Computer Science, IMS Engineering College, Ghaziabad, U.P., India

Vijai Singh is a Assistant Professor in Department of Computer Science, IMS Engineering College, Ghaziabad, U.P., India. Pursuing PhD. From Uttarakand Technical University, Indian 